Piotr Z. Pomianowski (Warszawa)

\title{
Postulat narodowego charakteru prawa w pracach kodyfikacyjnych doby Królestwa Kongresowego*
}

Oba pojęcia składające się na hasło „kodyfikacja narodowa” mają charakter nieostry. Autor rozdziału Systemu prawa prywatnego poświęconego zjawisku kodyfikacji prawa prywatnego, Leonard Górnicki, stwierdza: „zwykliśmy dzisiaj w naszym kręgu kulturowym myśleć o kodyfikacji prawa jako o najwyższej pod względem techniki prawniczej formie systematyzacji przepisów prawnych, będącej całościowym, w miarę wyczerpującym unormowaniem jakiejś rozległej dziedziny życia, opartym na jednolitych założeniach światopoglądow y c h oraz dogmatycznych, a także na jednolitej metodzie regulacji prawnej pokrewnych stanów faktycznych i prawnych, w której wyraźny jest element nowości rozwiązań jurydycznych, to znaczy twórczej inwencji, a nie tylko uporządkowania czy ujednolicenia istniejącego stanu"1. Dostrzegając pewne mankamenty (nieostrość), wobec braku lepszej definicji, przyjmijmy tę za własną.

Jeszcze bardziej problematyczne okazuje się zdefiniowanie „narodu”. Pomimo hektolitrów przelanego atramentu ,pojęcia narodu, państwa narodowego, nacjonalizmu i tożsamości narodowej należą do najbardziej kontrowersyjnych terminów socjologicznych, a ich definicja nastręcza najwięcej trudności”². We współczesnej socjologii szczególnie popularne jest określanie narodów mianem

* Tekst przygotowany w ramach projektu Kodyfikacja narodowa - fantazmat czy realna alternatywa? W kręgu debat nad rodzimym systemem prawa sądowego w konstytucyjnym Królestwie Polskim finansowanego przez Narodowe Centrum Nauki (UMO-2015/18/E/HS5/00762).

${ }^{1}$ M. Safjan (red.), System prawa prywatnego, wyd. 2, Warszawa 2012, t. 1, s. 78, wyróżnienia moje - P.Z.P.

2 A. Giddens, Socjologia. Kluczowe pojęcia, Warszawa 2014, s. 282-283; T. Kizwalter, O nowoczesności narodu. Przypadek polski, Warszawa 1999, s. 11 i n. Względnie aktualny, wyczerpują- 
„wspólnot wyobrażonych" ${ }^{\text {i }}$ marginalizowanie prób definiowania narodu poprzez więzy krwi (ujęcie rasowe) $)^{4}$.

Niemniej jednak za Praktycznym słownikiem wspótczesnej polszczyzny możemy powtórzyć, że naród to: „trwała wspólnota ludzi utworzona historycznie, wyróżniająca się wspólną świadomością narodową; zbiorowość ludzi mówiących tym samym językiem, mająca tę samą historię, kulturę oraz wspólną gospodarkę i politykę" ${ }^{5}$. To samo opracowanie przytacza i drugie znaczenie interesującego nas słowa, a mianowicie: „duże zgromadzenie ludzi w jednym miejscu”. Wcześniejszy o blisko dwieście lat słownik Samuela Bogumiła Lindego podaje te same dwa zasadnicze znaczenia, jednakże - co znamienne - w odwrotnej kolejności. Nas interesuje siłą rzeczy ta część hasła, w której Linde definiuje naród w sposób następujący: „nacja, cały ten zbiór ludzi jednego języka, jednych obyczajów, w jednym kraju osadzonych"6.

W osiemnastowiecznej publicystyce można spotkać zarówno węższe rozumienie pojęcia narodu jako szlachty, jak i szersze - obejmujące także plebejuszy ${ }^{7}$. Pod koniec stulecia niektórzy publicyści dokonali przewartościowania i za naród skłonni byli uznać wyłącznie pospólstwo ${ }^{8}$. Ale terminu „naród” używano także na określenie tego, co dzisiaj nazywamy państwem ${ }^{9}$ (utożsamianie narodu w dzi-

cy wykaz literatury dotyczącej pojęcia narodu można znaleźć w: M. Łuczewski, Odwieczny naród. Polak i katolik w Żmiacej, Warszawa 2012.

${ }^{3}$ Benedict Anderson proponuje ,następującą antropologiczną definicję narodu: jest to wyobrażona wspólnota polityczna, wyobrażona jako nieuchronnie ograniczona i suwerenna. Jest wyobrażona, ponieważ członkowie nawet najmniej licznego narodu nigdy nie znają większości swych rodaków, nie spotykają ich, nic nawet o nich nie wiedzą, a mimo to pielęgnują w umyśle obraz wspólnoty (...) Narody wyobrażone są jako wspólnoty ograniczone, ponieważ nawet największe z nich, liczące nawet miliard żywych istot ludzkich, zajmują skończony (...) obszar, poza którym żyją inne narody. Żaden naród nie wyobraża sobie siebie jako całej ludzkości”. Idem, Wspólnoty wyobrażone. Rozważania o źródłach i rozprzestrzenianiu się nacjonalizmu, Kraków 1997, s. 19-20.

${ }^{4}$ A. Kłoskowska, Kultury narodowe u korzeni, Warszawa 2012, s. 17.

${ }^{5}$ H. Zgółkowa (red.), Praktyczny słownik współczesnej polszczyzny, Poznań 1999, t. 23, s. 9.

${ }^{6}$ S.B. Linde, Stownik Języka Polskiego, Warszawa 1809, t. 3, s. 252, szpalta lewa.

7 T. Kizwalter, O nowoczesności..., s. 94-95. Zdarzało się też traktowanie Wielkopolan, Małopolan i Litwinów jako osobnych narodów, jak również określanie wszystkich Słowian mianem narodu (J. Maciejewski, Pojęcie narodu w myśli republikanów lat 1767-1775, [w:] J. Goćkowski i A. Walicki (red.), Idee i koncepcje narodu w polskiej myśli politycznej czasów porozbiorowych, Warszawa 1977, s. 27).

8 J. Maciejewski, Pojęcie narodu..., s. 40. To rewolucyjne pojmowanie narodu propagował Franciszek Salezy Jezierski.

9 J. Maciejewski, Pojęcie narodu..., s. 28 i 40. Z takim użyciem interesującego nas pojęcia spotykamy się m.in. w Ustawie Rządowej. W jej art. 4 pada następujące stwierdzenie: „lud rolniczy (...) najliczniejszą w narodzie stanowi ludność". Twórcy konstytucji używali omawianego słowa w różnych znaczeniach. Por. też: H. Kołłątaj, O Ustanowieniu I Upadku Konstytucyi Polskiey $3 g o$ Maia 1791, Metz 1793, s. 119. Podobnie: Odezwa Jana Henryka Dąbrowskiego i Józefa Wybickiego do rodaków z 3 XI 1806 roku: „Polacy! Napoleon Wielki, niezwyciężony, wchodzi w trzykroć 
siejszym tego słowa znaczeniu z państwem nastręczało pytanie, czy zbiorowość, która utraciła własną państwowość nadal pozostaje narodem ${ }^{10}$ ). $\mathrm{Z}$ tym przede wszystkim kontekstem znaczeniowym skłonny jestem wiązać obecny w osiemnastowiecznej polszczyźnie związek frazeologiczny: ,prawa narodowe”"11.

sto tysięcy wojska do Polski. Nie zgłębiajmy tajemnic zamysłów, starajmy się być godnymi jego wspaniałości. »Obaczę (powiedział nam), obaczę, jeżeli Polacy godni są być Narodem«”. R. Bielecki, A. Tyszka, Dat nam przykład Bonaparte. Wspomnienia i relacje żolnierzy polskich 1796-1815, Kraków 1984, t. 1, s. 135, wyróżnienie moje - P.Z.P. Oczywiście w tym wypadku - zakładając, że cytat jest prawdziwy - winniśmy odwołać się do denotacji francuskiego nation. A wśród desygnatów tej nazwy znajdowało się rzecz jasna i to, co zwykliśmy nazywać państwem - por. P. Larousse, Le Grand dictionnaire universel du XIXe siècle, Paris 1874, t. 11, s. 854. Takież znaczenie spotykamy w zdaniu rozpoczynającym dzieło Tadeusza Czackiego O litewskich polskich prawach ...: „Już Polska wymazana jest z liczby narodów" (Warszawa 1800, t. 1, s. IV). Ze złączeniem narodu i państwa mamy także do czynienia w Mazurku Dąbrowskiego: „Przejdziem Wisłę, przejdziem Wartę, będziem Polakami”. Zatem polscy legioniści we Włoszech mieli się stać Polakami dopiero po odbudowie ojczyzny. Takiż zakres znaczeniowy pojawia się w słynnym stwierdzeniu niesławnego Szczęsnego Potockiego: „Każdy z przeszłych Polaków ojczyznę sobie obrać powinien. Ja już jestem Rosjaninem na zawsze” (cyt. za: R. Przybylski, Klasycyzm, czyli prawdziwy koniec Królestwa Polskiego, Warszawa 1983, s. 138). Takie też rozumienie słowa „Polak” spotykamy w odnoszącym się do mieszkanki Wielkiego Księstwa Poznańskiego, która poślubiła obywatela Królestwa Polskiego, stwierdzeniu, że „idąc za mąż za Polaka staje się Polką” („Themis Polska” 1830, t. VII, s. 227). Zob. w końcu I. Stawiarski, Rozprawa o użyciu i przystosowaniu księgi niniejszej do potrzeb legislacji Narodu Polskiego, [w:] Ogólna Ordynacya Sądowa dla Państw Pruskich, Warszawa 1807, t. 1, s. V: „,należy się odrodzić politycznie, abyśmy zasłużywszy przez stałość, waleczność i ducha publicznego na byt i jestestwo, stanęli znowu w rzędzie niepodległych Narodów Europy". Rzecz jasna dostrzegano również możliwość istnienia narodu bez państwa dążenia do odbudowy państwowości (zob. np. akt zawiązania Deputacji Polskiej w Paryżu z 22 sierpnia 1795 r. - wyd. W. Smoleński, Emigracja polska w latach: 1795-97 (materiaty historyczne), „Przegląd Historyczny” 2011, z. 1, s. 64-66.

10 J. Czubaty, Zasada „dwóch sumień”. Normy postępowania i granice kompromisu politycznego Polaków w sytuacjach wyboru (1795-1815), Warszawa 2005, s. 107.

${ }^{11}$ Por. Rezolucja na memoriat braci Greczyńskich skarżacych Młodeckiego o przemoc i niepodporzadkowanie się rezolucji Rady Nieustajacej w zwiazku ze sporem toczonym o dziedzictwo dóbr Koszowata oraz memoriał Młodeckiego zarzucajacego rzekomym Greczyńskim podszywanie się pod prawowitych dziedziców tych dóbr, wyd. M. Głuszak, Zbiór rezolucji interpretacyjnych Rady Nieustającej z lat 1786-1788, Łódź 2014, s. 292-293: „Rezolwując memoriał ur. Jana Greczyńskiego, który swoim i brata swego imieniem zaskarża ur. Młodeckiego, dóbr Koszowata zwanych, w województwie kijowskim leżących, feudalnego posesora, iż tenże, ani na rezolucję Rady Naszej stosownie do p raw n a r od ow y c h 1786 roku wydaną, ani na list salvi conductis, które to tymże ur. Greczyńskim, ich osób bezpieczeństwo od wszelkiej prywatnej przemocy warują, najmniej nie zważając, a chcąc jeszcze, iżby nie mogli być w stanie dochodzenia dziedzictwa części tychże samych dóbr Koszowata, sobie pretendowanego, ichże obudwóch zamknąć w więzieniu (...) ważył się (...) My Król (...) deklarujemy: Iż rezolucja Rady Naszej dnia 30 czerwca 1786 r., na memoriały tak tychże Greczyńskich jako i ur. Młodeckiego wydana, w słowach: »Gdy p ra wa narodowe nikomu własną mocą nie dozwalają sprawiedliwości sobie czynić, a na wszystkie przypadki mieszkańców Rzeczypospolitej przeznaczone są jurysdykcje, przeto w sprawie de natura bonorum, gdy już zaszłe dekreta w sądach Naszych zadwornych Asesoryi Koronnej nastąpiły, do tejże więc jurysdykcyi, strony żalące się udać się mają« będąca, jest i na teraźniejsze tychże 
W swojej historii Polacy kilkukrotnie stanęli przed problemem kodyfikacji prawa ${ }^{12}$. Wskazać możemy zasadniczo dwa okresy, w których prowadzono szeroko zakrojone prace kodyfikacyjne spełniające z grubsza kryteria zawarte w zacytowanej wyżej definicji Leonarda Górnickiego. Pierwszy to czasy konstytucyjnego Królestwa Polskiego, drugi - obejmuje prace nad unifikacją i kodyfikacją prawa po odzyskaniu niepodległości. Natomiast przedsięwzięcia podejmowane w okresie przedrozbiorowym (Korektura praw, Statuty litewskie, Korektura pruska, Kodeks Zamoyskiego) nie spełniały w mojej opinii kryteriów przyjętej definicji, ponieważ ich twórcy koncentrowali się na porządkowaniu istniejących norm, a nie na ich zmienianiu na bazie jednolitych założeń światopoglądowych ${ }^{13}$.

Tak w wieku XIX, jak i XX w trakcie prac kodyfikacyjnych pojawiał się postulat, by prawo miało charakter narodowy (czy też mówiono po prostu o tworzeniu ,prawa narodowego"). Rzadko jednak wyjaśniano, co konkretnie ma to oznaczać. Można jednak odnieść wrażenie, że przymiotnik „narodowy” używany był w co najmniej trzech podstawowych znaczeniach - czasem zresztą we wszystkich naraz.

stron memoriały dostateczną odpowiedzią. Żeby zaś ciż Greczyńscy, oprócz tej obrony, którą mają w prawach narodow y ch przeciwko wszelkiej nad ich osobami przemocy, być mogli jeszcze, i ex jure Majestatico listem salvi conductus, aż do ostatecznej rozprawy zasłonieni, o wyjednanie onegoż do kancelaryi koronnej udać się mogą", wyróżnienia moje - P.Z.P. Takież znaczenie: T. Czacki, O litewskich polskich prawach..., Warszawa 1800, t. 1, s. 2. Odmiennie jednak użył interesującego nas terminu Stanisław Staszic w następującym apelu do Rosjan: „Polacy są nieudolni być waszymi niewolnikami, ale są przygotowani stać się waszymi braćmi. Połączcież ten naród z właściwą mu ustawą narodowego prawa i rządu pod jednym cesarzem i królem w wielką rzeszę Cesarstwa”. S. Staszic, Myśli o równowadze politycznej w Europie, [w:] idem, Pisma filozoficzne i społeczne, Warszawa 1954, t. 2, s. 318-319. Maurycy Mochnacki jeszcze mocniej akcentował oryginalność i swoistość tego, co narodowe (T. Kizwalter, O nowoczesności narodu..., s. 178). Nie wydaje się jednak, aby jego romantyczny sposób myślenia był szczególnie popularny wśród prawników pracujących nad kodyfikacją narodową.

12 Poza pracami w Królestwie Kongresowym można wskazać na przygotowaną w tej samej epoce kodyfikację prawa dla Obwodu Białostockiego. Mamy tu do czynienia z kompilacją istniejących źródeł, przy czym nic nie wskazuje na próbę nadawania jej narodowego charakteru. Zob. Projekt prawa prowincjonalnego Obwodu Białostockiego z 1811 roku, tekst do druku przygotowali i oprac. K. Łopatecki i M. Piłaszewicz-Łopatecka, wstępem opatrzyli S. Godek i K. Łopatecki, Białystok - Oświęcim 2015.

${ }^{13}$ E. Borkowska-Bagieńska, Zbiór praw sądowych Andrzeja Zamoyskiego, Poznań 1986, s. 326-327. Z kolei w dobie Sejmu Wielkiego podjęto prace nie tylko porządkujące, ale i reformujące porządek prawny. Niemniej jednak po upadku Rzeczypospolitej wiedza o nich była niewielka. W. Szafrański, Kodeks Stanisława Augusta, Poznań 2007, s. 319; idem, Józef Weyssenhoff: polityk, prawnik, legislator czasów Oświecenia, Poznań 2017, s. 353 i n. Rzecz prosta, ostre określenie kodyfikacji, jak i wielu innych zjawisk, jest niezmiernie trudne i w pewnym zakresie zależy od uznania poszczególnych autorów. 
Po pierwsze, „kodeksem narodowym” mógł być po prostu kodeks spisany w języku narodowym, czyli po polsku ${ }^{14}$. Przypomnieć należy, że większość ustaw odziedziczonych po Francuzach, Prusakach i Austriakach, które obowiązywały na obszarze Królestwa Kongresowego, nie miała urzędowych tłumaczeń na język polski ${ }^{15}$. Drugie znaczenie jest równie prozaiczne: prawo narodowe mogło być synonimem ustawodawstwa obowiązującego w państwie polskim ${ }^{16}$. W końcu, po trzecie, mogło to być prawo o rodzimej genezie ${ }^{17}$, dostosowane do warunków miejscowych (w tym do mentalności społeczeństwa), a czasem wręcz prawo specyficzne odróżniające naszą wspólnotę od innych ${ }^{18}$. Tak postrzegał prawo książę

${ }^{14}$ Por. art. 84 konstytucji Księstwa Warszawskiego tudzież następujące wycinki z afiszów teatralnych: „W pałacu Spizkim na Teatrze publicznym teraz zupełnie odnowionym i ku naywiększey wygodzie wyreparowanym, Aktorowie n arodow i będą mieli honor dać dziś w Niedzielę t.j. dnia 16 Stycznia r. 1785, Komedyę w trzech aktach pod tyt: Obrotny sługa nieroztropnego Pana czyli Krętolewicz (...) Kompania w ło s k a będzie miała honor w Niedzielę t. j. dnia 16 Grudnia tu na teatrze w Spizkim pałacu będącym, dać pierwszą reprezentacyą opery nowey w dwoch aktach: $L a$ semplice, o Tuttore burlato, czyli: Prostaczka, albo opiekun oszukany, która o samey godzinie 6tey zaczynać się będzie. (...) Ostrzega się prześw. Publicum, iż treści opery dokładnie wytłomaczoney przy braniu biletów w kassie exemplarz osobny po gro. 15 wydawany będzie”. Cyt. za: „Biblioteka Warszawska. Pismo poświęcone naukom, sztukom i przemysłowi” 1847, t. 3, s. 179-180, wyróżnienia moje - P.Z.P.

${ }_{15}$ Wyjątek stanowiła monarchia Habsburgów: F. Kappler, Handbuch der Literatur des Criminalrechts und dessen philosophischer und medizinischer Hülfswissenschaften, Stuttgart 1838, s. 32; S. Grodziski, Studia Galicyjskie, Kraków 2007, s. 22.

${ }^{16}$ Zob. przypis 12.

${ }^{17} \mathrm{Na}$ ten aspekt zwraca uwagę J. Wesołowski, Rozprawa z powodu rozszerzajacego się coraz bardziej mniemania $w$ kraju wołyńskim, że opieka męża nad żona jest niestusznościa, że żony powinny mieć wolność niezaprzeczonego władania własnemi majątkami, jakie maja mężowie co do swoich, że nie masz żadnego między polskiemi prawami, coby nadawało przewage i opiekę mężowi nad żona, że statut litewski, jedyne wołyńskie prawo, nadaje moc żonom czynienia zapisów dla mężów i dla kogo zechca; z rozbiorem, czy takowe twierdzenia rozszerzajace się zgadzaja się z prawda, prawem natury, doświadczeniem, i jakie ich skutki?, Krzemieniec 1815, s. 3.

${ }_{18}$ Zdaje się, że takie rozumowanie było szczególnie popularne w wieku XIX na Zachodzie, kiedy własną kodyfikację (w szczególności prawa cywilnego) uznawano za element utrwalający narodową jedność i silnie powiązaną z państwem narodowym. System prawa prywatnego..., s. 87; R. Zimmermann, Dziedzictwo Savigny'ego. Historia prawa, prawodawstwo porównawcze i ksztattowanie sie europejskiej nauki prawa, „Kwartalnik Prawa Prywatnego” 2005, r. 14, z. 1, s. 13-14. W okresie konstytucyjnego Królestwa Kongresowego utożsamianie pojęcia „ustaw narodowych” ze specyficznie polskimi obyczajami możemy spotkać m.in. u Joachima Lelewela (Początkowe Prawodawstwo Polskie, Cywilne i Kryminalne, do czasów Jagiellońskich, Warszawa 1828, przykładowo: s. 338-339; należy jednak zauważyć, że praca ta dotyczy dosyć odległej epoki). W tym kontekście możemy przytoczyć także następujące stwierdzenie Ignacego Stawiarskiego: „Naród, którego szlachetny charakter nie cierpi obłudy, ani skrytych sposobów działania; Naród szczery i uprzejmy, nie zniósłby narzuconego sobie, trybu w sądownictwie, który zamykając mu, oczy przed Sądem, odpycha go od jego kratek, który odejmując stronom pociechę przysłuchania się, jak są bronione przez swych prawnych zastępców, wprowadza je w szkodliwe podejrzenia względem władzy, która w szanownej zawsze postawie wydawać się powinna oczom publiczności" (I. Stawiarski, Rozprawa 
Adam Jerzy Czartoryski pisząc o „stracie, którą ponosi naród, kiedy obce prawa mu nadają, a z niemi obce zwyczaje i czucia, tak, iż tracąc swoją oryginalność, utracą razem swoje dobre własności, a po większej części cudze przywary natomiast nabywa"19. W tym kontekście warto również przytoczyć opinię Romualda Hubego, który proponował oparcie prawodawstwa narodowego na materiałach pochodzących ,z życia narodowego, z praktyki własnej sądowej, nadto z pojęć nam właściwych"20.

Jak już wspomniałem, w obydwu okresach prac kodyfikacyjnych mówiono i pisano o tworzeniu prawa narodowego. Niestety, żaden z autorów czynnych w Królestwie Kongresowym nie pozostawił po sobie głębszych rozważań teoretycznych na temat tego, co winno wyróżniać prawo narodowe. Niemniej jednak w wypowiedziach takich wybitnych prawników epoki, jak Antoni Wyczechowski czy Antoni Bieńkowski możemy odnaleźć pewne refleksje na interesujący nas temat.

Pierwszy z wymienionych nie dostrzegał zbyt wielu elementów oryginalnych w prawach koronnych i litewskich:

Co dziś nazywamy prawem narodowym polskim są to tylko modyfikacje praw rzymskich i kanonicznych, które się utworzyły przez zmieszanie tychże praw z prawami i zwyczajami narodowymi i przez wpływ sąsiedzkich praw i zwyczajów ${ }^{21}$.

Zarazem ten - w istocie eklektyczny - system prawny w żadnej mierze nie przystawał do realiów początku XIX wieku:

nie masz tych interesów, tych stosunków, tych wyobrażeń, tych zwyczajów, dla których były te prawa stosownymi. Dzisiejsze przypadki są subtelniejsze, powiązane z wyobrażeniami, któreśmy od obcych praw i narodów przejęli. To przeistoczenie stało się już naszą własnością, nikt

o użyciu i przystosowaniu księgi niniejszej do potrzeb legislacji Narodu Polskiego, [w:] Ogólna Ordynacya Sądowa dla Państw Pruskich, Warszawa 1807, t. 1, s. XIII); Por. też K. Koźmian, Pamiętniki, Poznań 1825, t. II, s. 231 oraz Biblioteka Książąt Czartoryskich w Krakowie, rkps 5233, Protokót posiedzeń Komitetu Reformy od jego rozpoczęcia się dnia 4 lipca 1814, zwłaszcza k. 12, 22, 328 i 418.

19 Cytat za: I. Daniłowicz, Kodex Napoleona w porównaniu z prawami polskiemi i litewskiemi, wyd. A. Kraushar, Warszawa 1905, s. 177.

${ }^{20}$ R. Hube, Uwagi nad systematem Kodexu cywilnego francuskiego, „Themis Polska”, t. V, Warszawa 1829, s. 298.

${ }^{21}$ A. Wyczechowski, Myśli względem prawodawstwa narodowego, Biblioteka Książąt Czartoryskich w Krakowie, rkps 5259, s. 62. Memoriał Wyczechowskiego nie jest datowany. Zapewne powstał on przed 27 listopada 1815 roku, czyli datą oktrojowania konstytucji Królestwa Polskiego, skoro autor twierdzi, iż prace nad reformą prawa należy rozpocząć od przygotowania „statutu konstytucyjnego" (s. 83). Prawo kanoniczne, w odniesieniu do spraw małżeńskich, za narodowe uznawał także Stanisław Grabowski - zob. H. Konic, Dzieje prawa matżeńskiego w Królestwie Polskim (1818-1836), Kraków 1903, s. 15. Por. też K. Koźmian, Pamiętniki, Poznań 1825, t. I, s. 25. Nie byli oni w tym osamotnieni. Stanisław Węgrzecki krytykuje ten pogląd w: Antikodexistów: Uwagi nad I ksiegga Kodeksu Cywilnego francuskiego, „Dekada Polska” 1821, nr 7, s. 296-297. 
już tego nie wygładzi, bo nikt przeszłości zmienić nie potrafi. Dla tych przypadków dawne prawa żadnych nie obejmują prawideł, bo ich wcale znać nie mogły. Nie obejdzie się więc bez dodatków i zmian, a te muszą koniecznie tchnąć obcym duchem, bo się muszą stosować do przypadków, które się utworzyły z wyobrażeń od obcych przejętych ${ }^{22}$.

W tej sytuacji - zdaniem Wyczechowskiego - należało dokonać syntezy wszystkich obowiązujących dotąd systemów prawnych, wybierając z każdego z nich to, co najlepsze ${ }^{23}$. Autor ten uznawał Kodeks Napoleona za narodowy w tym sensie, że w przeciwieństwie do praw pruskich i austriackich był on znany wszystkim prawnikom Królestwa Polskiego ${ }^{24}$. Oceniał go wysoko, podkreślając, że zawarte $\mathrm{w}$ nim prawo rzeczowe oparte jest na wzorcach prawa rzymskiego ${ }^{25}$. Dostrzegał jednocześnie, że prawo osobowe odwołuje się w znacznym stopniu do ideałów Rewolucji Francuskiej, co w jego mniemaniu nie było dyskwalifikujące, skoro w samej Francji po restauracji Burbonów pozostawiono te przepisy w mocy ${ }^{26}$, a i król pruski - wykorzystując Kodeks Napoleona - zmienił w pewnym zakresie uregulowania Landrechtu dotyczące osób ${ }^{27}$. Poglądy te korespondowały z utylitarnym rozumieniem narodowej kodyfikacji:

prawami narodowymi są te, które uznane będą jako najbardziej odpowiadające dzisiejszej cywilizacji i najdogodniejsze do ugruntowania szczęścia mieszkańców Królestwa Polskiego, bez względu na źródło, z którego są czerpane ${ }^{28}$.

Zatem oryginalnie polskie pochodzenie instytucji prawnych nie stanowiło według Wyczechowskiego o ich szczególnej wartości. Niemniej jednak w jego opinii prace kodyfikacyjne należało rozpocząć od uporządkowania praw polskich,

${ }^{22}$ A. Wyczechowski, Myśli względem..., s. 80-81. Aktualne omówienie memoriału można znaleźć w: M. Gałędek, A. Klimaszewska, A Controversial Transplant? The Debate on the Adaptation of the Napoleonic Code on Polish Territories in the Early Nineteenth Century, ,Journal of Civil Law Studies" 2018, nr 2. Już za panowania Stanisława Augusta prawo koronne uważano za przestarzałe. J. Michalski, Zagadnienie reformy sądownictwa i prawa sądowego w początkach panowania Stanistawa Augusta, „Czasopismo Prawno-Historyczne” 2000, t. 52, nr 1-2, s. 97 i n. Podobnie na krótko przed proklamowaniem Księstwa Warszawskiego Ignacy Stawiarski pisał: „walcząc nieprzyjaciół naszych, ścigając najezdników, zrzucając jarzmo narzuconego języka i podległości, szanujmy dobre Prawa, zachowujmy wprowadzony zbawiennie porządek, i nie łudźmy się, że nasze dawne ustawy, lubo dobre i szacowne dla owych czasów, mogą być teraz prawidłem dla odrodzonych Polaków I. Stawiarski, Rozprawa o użyciu i przystosowaniu księgi niniejszej do potrzeb legislacji Narodu Polskiego, [w:] Ogólna Ordynacya Sądowa dla Państw Pruskich, Warszawa 1807, t. I, s. V.

${ }^{23}$ A. Wyczechowski, Myśli względem ..., s. 82.

${ }^{24}$ Ibidem, s. 79.

${ }^{25}$ Ibidem, s. 76.

${ }^{26}$ Jak się miało okazać - do czasu, wkrótce bowiem zniesiono rozwody: Loi sur l'abolition du divorce (8 - 10 mai 1816), [w:] J.B. Duvergier, Collection complète des lois, décrets, ordonnances, réglements, avis du Conseil d'État, Paris 1827, t. 20, s. 464-465.

27 A. Wyczechowski, Myśli względem ..., s. 77.

${ }^{28}$ Ibidem, s. 84. 
pruskich i galicyjsko-austriackich według systematyki przyjętej przez ustawodawstwo napoleońskie (tylko ono było znane na obszarze całego kraju ${ }^{29}$ ).

Zaproponowane przez Wyczechowskiego prace były rzecz jasna najtrudniejsze w odniesieniu do praw staropolskich, które w przeciwieństwie do pozostałych nie zostały skodyfikowane (rozwój polskiego prawa zatrzymał się w XVIII wieku, kiedy Rzeczpospolita przeżywała głęboki kryzys zakończony jej upadkiem ${ }^{30}$ ). Należało zatem wykorzystać pochodzące z różnych okresów statuty królewskie i ustawy sejmowe oraz literaturę prawniczą ${ }^{31}$, a zarazem zatrudnić żyjących jeszcze prawników, którzy byli aktywni w epoce przedrozbiorowej, do stworzenia „doskonałego zbioru praw ojczystych”32. Prawa uczono się bowiem w dawnej Polsce przede wszystkim poprzez praktykę i najlepszym źródłem, z którego można skorzystać przy jego opisie, była pamięć tych, którzy je stosowali33. Ten sposób kształcenia prawników uległ załamaniu wraz z upadkiem państwa polskiego (przynajmniej na obszarach wcielonych do Prus i do Austrii, gdzie szybko wprowadzono nowe, obce kodeksy - inaczej rzecz się miała w zaborze rosyjskim, gdzie przez kilkadziesiąt lat utrzymały się dawne prawo i dawne sądy ${ }^{34}$ ). Szczególnie drastyczne jednak odcięcie od staropolskiej kultury prawnej nastąpiło w zaborze pruskim, gdzie wprowadzono Landrecht, choć zastrzeżono, że do pewnych spraw (np. spadkowych) będą nadal stosowane prawa staropolskie ${ }^{35}$. Jednocześnie nakazano sądom procedowanie w języku niemieckim, który nie był znany większości ówczesnych polskich prawników. Oznaczało to w praktyce, że urzędy sądowe objęli przeważnie przybysze $\mathrm{z}$ innych pruskich prowincji (narodowości niemieckiej), kariery sędziów Polaków zaś zostały przerwane. Zarazem sędziowie Niemcy mieli poważne kłopoty ze stosowaniem praw staropolskich w sprawach, które teoretycznie powinny być rozstrzygane na ich podstawie, i zamiast nich stosowali Landrecht (często nie znali języka polskiego, a ponadto zapoznanie się z rozproszonymi źródłami prawa, wśród których poczesne miejsce zajmował zwyczaj, było niezwykle trudne) $)^{36}$. Co prawda ówczesna monarchia pruska - inaczej niż w drugiej połowie XIX wieku - nie wykluczała Polaków z pełnienia urzędów państwowych, ale od kandydatów wymagała znajomości języka niemieckiego. Oznaczało to, że kariera publiczna była otwarta głównie dla młodych, którzy na

${ }^{29}$ Ibidem, s. 84-86.

${ }^{30}$ Ibidem, s. 66.

${ }^{31}$ Ibidem, s. 85.

32 Ibidem, s. 70.

33 Ibidem, s. 66.

${ }^{34}$ S. Godek, III Statut Litewski w dobie porozbiorowej, Warszawa 2012, s. 711 i n.

35 Problem omówiony w: Z. Radwański, J. Wąsicki, Wprowadzenie pruskiego prawa krajowego na ziemiach polskich, „Czasopismo Prawno-Historyczne” 1954, t. 6, z. 1, s. 184-220.

${ }^{36}$ A. Wyczechowski, Myśli względem ..., s. 71. 
etapie edukacji poznali język monarchii. W konsekwencji, gdy w roku $1806 \mathrm{Na}-$ poleon zaczął odtwarzać państwo polskie, na odebranych królowi pruskiemu terytoriach pracowała pewna liczba sędziów Polaków, ale byli to przeważnie ludzie młodzi, nieznający zwyczajów staropolskich - „cudzoziemcy w swoim własnym kraju" 37 .

Nieco inaczej rzecz się miała w zaborze austriackim, gdzie obowiązywały ustawy ogłaszane w przeważającej mierze jednocześnie po niemiecku, po polsku i po łacinie, a sądy procedowały w języku łacińskim, który był znany sędziom sądów ziemskich, a co za tym idzie, staropolscy sędziowie nie zostali wykluczeni z sądownictwa ${ }^{38}$. Niemniej jednak, mimo wszystkich różnic szczegółowych, prawa staropolskie, pruskie i galicyjskie miały pewne zasadnicze cechy wspólne, a mianowicie stanowość i przywiązanie do feudalnych instytucji. Pod tym względem wszystkie też różniły się istotnie od prawa francuskiego ${ }^{39}$.

Znamienne, że Wyczechowski w ogóle nie rozważał możliwości wykorzystania osiemnastowiecznych projektów kodeksów (Andrzeja Zamoyskiego i Stanisława Augusta $)^{40}$ ani archiwów sądów staropolskich, choć istnienie tych ostatnich dostrzega ${ }^{41}-\mathrm{w}$ tym przypadku zapewne decydująca była szczególna czasochłonność ewentualnych prac nad tego typu źródłami - niezwykle obfitymi. Trudniej natomiast wyjaśnić przyczyny pominięcia projektów kodeksów, których wykorzystanie nie rodziło żadnych istotnych komplikacji ${ }^{42}$. Nie wyjaśnił też Wyczechowski, czy chciałby zaproszenia do prac sędziów ze wszystkich sądów funkcjonujących w dawnej Rzeczypospolitej (szlacheckich, miejskich, wiejskich, żydowskich...). Można jednak przypuszczać, że miał na myśli wyłącznie sądy ziemskie ${ }^{43}$.

${ }^{37}$ Ibidem, s. 72-73. W rzeczywistości sprawa była bardziej złożona. Por. J. Wąsicki, Ziemie polskie pod zaborem pruskim. Prusy Poludniowe, Wrocław 1957, s. 131; idem, Ziemie polskie pod zaborem pruskim. Prusy Nowowschodnie, Poznań 1963, s. 77 i n.; B. Wachowiak (red.), Prusy w okresie monarchii absolutnej (1701-1806), Poznań 2010, s. 344-348 i 781-784.

${ }^{38}$ A. Wyczechowski, Myśli względem.... Józef Wawel-Louis zwraca jednak uwagę na to, że Polacy zostali w hierarchii sądowej zepchnięci na pośrednie stanowiska (Sądownictwo w Królestwie Galicji <1784-1855>, ,Przegląd Prawa i Administracji” 1899, t. 24, s. 355 i n.), por. J. Wawel-Louis, Początkowe sadownictwo austriackie w Galicji (1772-1784), Lwów 1897, s. 16 i n., S. Grodziski, Historia ustroju społeczno-politycznego Galicji (1772-1848), Wrocław - Warszawa - Kraków - Gdańsk 1971, s. 218-219; J. Bardach i M. Senkowska-Gluck (red.), Historia państwa i prawa Polski, Warszawa 1983, t. 3, s. 747-748;

${ }^{39}$ A. Wyczechowski, Myśli względem..., s. 75-76.

${ }^{40}$ Ibidem, s. 84: „prawa polskie nie są zebrane w jedno ciało porządkiem systematycznym”.

${ }^{41}$ Ibidem, s. 66.

${ }^{42} \mathrm{~W}$ przypadku kodeksu Stanisława Augusta decydujący mógł być brak wiedzy o nim por. przypis 11 .

${ }^{43} \mathrm{Na}$ nieprawidłowość utożsamiania prawa staropolskiego z prawem ziemskim zwrócił uwage Stanisław Wegrzecki w: Uwagi nad I księga ..., s. 308. 
Drugim autorem poruszającym stosunkowo szeroko interesującą nas problematykę był Antoni Bieńkowski. Za czasów Komitetu Cywilnego Reformy wykonał on potężną pracę polegającą na wskazaniu w Volumina legum oraz III Statucie Litewskim konkretnych uregulowań, które należałoby uwzględnić w pracach kodyfikacyjnych ${ }^{44}$. Tym niemniej opowiadał się za doktryną uniwersalnego prawa natury (przynajmniej w odniesieniu do prawa cywilnego ${ }^{45}$ ), która stała w sprzeczności z samą ideą narodowego charakteru prawa. Pięć lat później w Przedstawieniu i wyttumaczeniu planu części pierwszej kodeksu cywilnego z 10 stycznia 1819 roku Bieńkowski pisał:

Widoczną zatem jest rzeczą, że ustawy cywilne nie do narodowości, która jest tworem wypadkowym, po różnych narodach rozmaitym, we wszystkich prawie często zmiennym, a w niektórych czasem mniej moralnym, lecz te ustawy powinny się stosować do moralności, która nie jest zmienną, jedną i tąż samą zawsze i wszędzie dla każdego człowieka, dla wszystkich narodów i dla całego rodzaju ludzkiego ${ }^{46}$.

Podczas prac w dobie Królestwa Kongresowego zauważalny był wpływ dawnego prawa polskiego i próby dostosowania ustawodawstwa do mentalności Polaków. Nie polegało to jednak na przywracaniu mocy obowiązującej konstytucjom sejmowym ani na opisywaniu językiem prawa pozytywnego dawnych norm zwyczajowych $^{47}$. Możemy raczej dostrzec próby odnajdywania w ustawodawstwach obcych, które obowiązywały na ziemiach polskich (niekoniecznie tylko w granicach Królestwa), uregulowań podobnych do dawnego prawa polskiego lub odpowiadających przekonaniom społecznym (przykładem tego ostatniego może być prawo osobowe małżeńskie).

Ten sposób działania w odniesieniu do prawa spadkowego (abstrahując od prawidłowości jego ocen) drobiazgowo wyjaśnił Bieńkowski:

${ }^{44}$ A. Bieńkowski, Stan czyli prospekt do kodeksu cywilnego, Biblioteka Książąt Czartoryskich w Krakowie, rkps nr 5236, s. 299 i n. Można jednak przy tym postawić pytanie czy przygotowane w ten sposób „wypisy” odnoszące się wyłącznie do prawa pisanego (a pomijające tak istotne w dobie staropolskiej zwyczaje) nie miały przekonywać czytelnika, że powrót do prawa przedrozbiorowego nie jest możliwy?

${ }^{45}$ „Co innego zaś prawa polityczne, kryminalne i policyjne, te muszą się różnic i zmieniać w stosunku do rozmaitych każdego kraju względów" - Biblioteka Książąt Czartoryskich w Krakowie, rkps 5233, Protokót posiedzeń Komitetu Reformy od jego rozpoczęcia się dnia 4 lipca 1814, k. 262.

${ }^{46}$ AGAD, Pierwsza Rada Stanu, sygn. 193, k. 9. Idei tej Bieńkowski pozostał wierny także w latach dwudziestych XIX wieku - P.Z. Pomianowski, Poczatki polskiego czasopiśmiennictwa prawniczego. Seria pierwsza ,Themis Polskiej”, Warszawa 2015, s. 105 i n.

${ }^{47} \mathrm{Z}$ takim procesem mieliśmy do czynienia na Węgrzech w drugiej połowie XIX wieku, co jednak należy uznać za sytuację niezwykłą. A. Almási, Ungarisches Privatrecht, Berlin - Leipzig 1924, s. 5 i n. 
Kodeks Austriacki ten pomysł ojców naszych, pierwej przywoływania wstępnych, a po nich, ich potomstwom, spadku jednymże i tym samym trybem, oddawania, sobie przyswoił, ponieważ jego §731 jak gdyby słowo w słowo z artykuł 13 naszej Korrektury jest wyjętym, a następne jego paragrafy jako to od 138 aż do końca, przez które, w każdym przypadku, gdzie który wstępny przywołany nie żyje, część jego potomstwu do podziału jednymże i tym samym trybem jest oddaną, zupełnie są pomysłem ojców naszych z artykuł 14 Korektury wyjętym a zatem samo przez się rozumie się, że ten pierwotny ojców naszych pomysł, nie tak, z kodeksu austriackiego przyjąć, jak raczej ten pomysł jako naszą własność, tę drogą po ojcach naszych spuściznę od tego kodeksu odzyskać i do naszego polskiego kodeksu na powrót odebrać należy. Idąc zawsze rzetelnie, poznaliśmy tę prawdę, że kodeks austriacki ten pomysł ojców naszych do siebie przyjęty dokładnie rozwinął, że wysłowienie tego kodeksu w tym rozwinięciu tak gładkie, proste, czyste, jasne i każdemu zrozumiałe, iż koniecznie temu kodeksowi przyznać musimy, te tym wysłowieniem wszystkie dotąd znane europejskie przepisy sukcesyjne daleko przewyższy ${ }^{48}$.

Rekapitulując: należy z poszczególnych kodeksów obowiązujących na ziemiach polskich wybrać te unormowania, które najlepiej odpowiadają naszej tradycji. Przywracanie praw dawnych nie jest jednak wskazane ze względu na niższy poziom techniki legislacyjnej.

Taki sposób myślenia i - co ważniejsze - działania możemy dostrzec, analizując poszczególne aspekty prac nad kodyfikacją narodową w Królestwie Polskim. Co prawda nie zmieniono prawa spadkowego, ale uchwalono prawo hipoteczne, małżeńskie osobowe, majątkowe małżeńskie, rodzinne i karne, ponadto zmieniono postępowanie egzekucyjne. Szczególnie w przypadku hipoteki i egzekucji zastosowano modus operandi postulowany przez Bieńkowskiego.

Przypomnijmy, że staropolskie prawo hipoteczne było pod wieloma względami bardziej zaawansowane od uregulowań Kodeksu Napoleona (znało choćby zasady jawności, szczegółowości i wieczystości wpisów, których zabrakło w Code civil). Nie może więc dziwić, że do zmiany tego działu prawa przystąpiono już na pierwszym sejmie Królestwa Kongresowego. W przedłożonym wówczas przez Antoniego Wyczechowskiego projekcie nowej ustawy aż pięćdziesiąt siedem artykułów było wzorowanych na prawie pruskim, a zaledwie dwa na staropolskim, pomimo że oba systemy regulowały interesującą nas instytucję - przynajmniej jeśli idzie o podstawowe zasady - w podobny sposób. Prawo pruskie stało jednak na wyższym poziomie legislacyjnym ${ }^{49}$.

48 [A. Bieńkowski], Upominek pogrobowy Ś. P. Kazimierza Pliszki Podlasianina. Rzecz o sukcesji, czyli uwagi nad prawem przyrodzonym do spadku, Warszawa 1827, s. 191-192. Kropkę nad i Bieńkowski postawił na s. 219: „to wysłowienie [tj. wersję austriacką] za wzór do naszego polskiego kodeksu przyjęliśmy".

${ }^{49}$ W. Wójcikiewicz, Prawo hipoteczne Królestwa Polskiego, Wrocław - Warszawa - Kraków 1967, s. 59. 
Podobnie było z egzekucją. Prawo staropolskie miało na względzie przede wszystkim interes szlachty ziemiańskiej, a nie kredytodawców. Zatem nie licytacja, lecz rodzaj przymusowej dzierżawy był zasadniczym sposobem egzekucji z nieruchomości w prawie ziemskim. Natomiast francuski Code de procédure civile z 1806 roku za podstawowy środek egzekucyjny w odniesieniu do nieruchomości uznał licytację (subhastację). Budziło to niezadowolenie szlachty, która szczególnie w okresie pruskim mocno się zadłużyła. Ogłaszano kolejne moratoria, aż w roku 1823 zmieniono francuskie przepisy i obok licytacji nieruchomości wprowadzono licytację jej dzierżawy. Rozwiązanie to do pewnego stopnia przypominało staropolską instytucję eksdywizji (potioritas), ale wydaje się, że W większym stopniu wzorowane było na prawie pruskim (sekwestr) ${ }^{50}$.

Z kolei zastąpienie napoleońskiej wspólności majątkowej jako ustawowego ustroju majątkowego małżeńskiego w roku 1818 przez rząd posagowy można uznać za bezpośrednie sięgnięcie do staropolskiej tradycji prawnej. Jednak już w roku 1825 rząd posagowy zastąpiono podobną do niego, lecz jednak nieco odmienną, pruską jednością zarządu ${ }^{51}$. Prawo małżeńskie osobowe zaś w roku 1825 uregulowano na wzór austriacki (system mieszany). Było ono inne od stosunków staropolskich (wówczas dziedzina ta była regulowana przez prawa wewnętrzne poszczególnych wyznań), ale zdaje się, że lepiej odpowiadało oczekiwaniom Polaków (a przynajmniej decydentów) niż w pełni świeckie prawo napoleońskie. Podkreślić jednak należy, że - według moich wyliczeń - około dwóch trzecich artykułów Księgi Pierwszej Kodeksu Cywilnego Królestwa Polskiego zostało wprost lub z modyfikacjami recypowane z Kodeksu Napoleona ${ }^{52}$.

Wobec powyższych uwag uzasadniony wydaje się pogląd, że tworzenie polskiego prawa narodowego w Królestwie Kongresowym polegało raczej na sięganiu do obcych wzorców, które odpowiadały miejscowym oczekiwaniom i były względnie spójne z naszą tradycją niż na przywracaniu do życia dawnych norm ${ }^{53}$.

${ }^{50}$ T. Królasik, Francuski model postępowania egzekucyjnego w Księstwie Warszawskim i w Królestwie Polskim w latach 1808-1823 (praca doktorska: Biblioteka Wydziału Prawa i Administracji Uniwersytetu Warszawskiego), Warszawa 2018, passim.

${ }^{51}$ Powody urzędowe do księgi pierwszéj kodeksu cywilnego Królestwa Polskiego z roku 1825. Z dyaryusza senatu sejmu Królestwa Polskiego z roku 1825, zebr. i ułożył M. Godlewski, Warszawa 1875, s. 231 i n. Por. Memorjat J. W. Bandtkiego o prawie hypotecznem z roku 1818, wyd. J.J. Litauer, Warszawa 1915.

${ }^{52}$ P. Pomianowski, The national codification of civil law in Poland at the beginning of the $19^{\text {th }}$ century. Sources and inspirations, [w:] V. Amorosi, V.M. Minale (ed.), History of Law and Other Humanities: Views of the Legal World Across the Time, Madrid 2019, s. 235-245.

${ }_{53}$ Tak też było z prawem karnym: J. Śliwowski, Kodeks karzacy Królestwa Polskiego, Warszawa 1958, s. 388. 
THE POSTULATE OF THE NATIONAL CHARACTER OF LAW

IN THE CODIFICATION WORKS DURING THE PERIOD OF THE KINGDOM OF POLAND

\section{Summary}

The purpose of this paper is to present the concept of the national codification of law in the Kingdom of Poland, especially of the postulate of creating new codes which would be compatible with the spirit of the Polish nation. It seems that this particular postulate was rather popular in that period. However, its supporters did not as a rule explain in detail their understanding of the idea under consideration.

Antoni Bieńkowski, a prominent lawyer and a member of the Codification Commission, was one of the exceptions. According to his publications, it can be stated that he suggested choosing solutions based on modern codes created in Western countries (France, Prussia, and Austria) which were compatible with the Polish legal tradition and with the expectations of the society in the Kingdom of Poland. At the same time, Bieńkowski did not consider it important that the Polish legal system and its institutions needed to be unique.

\section{POSTULAT DU CARACTERE NATIONAL DU DROIT DANS LES TRAVAUX DE CODIFICATION A L'EPOQUE DU ROYAUME DU CONGRES}

\section{Résumé}

Le but de cet article est de présenter l'idée de codification nationale au Royaume du Congrès, en particulier le postulat de l'élaboration de nouveaux codes conformes à l'esprit de la nation polonaise. Ce postulat semble avoir été populaire à cette époque. Néanmoins, ses partisans n'expliquaient généralement pas en détail comment ils comprenaient le concept en question.

Antoni Bieńkowski, grand juriste de cette époque, qui s’était longtemps engagé à élaborer les codes, présentait les opinions opposées. Il a postulé de choisir parmi les dispositions des lois modernes (française, prussienne et autrichienne) des solutions conformes à la tradition juridique polonaise et aux attentes de la société du Royaume du Congrès. Il estimait que les institutions qui composent le système juridique polonais ne devraient pas être uniques. 